\title{
PENGARUH FAKTOR MAKRO EKONOMI TERHADAP INDEKS HARGA SAHAM GABUNGAN DI BURSA EFEK INDONESIA (PERIODE 2010-2019)
}

\section{Qony Ratnasari, Sri Muljaningsih, Kiki Asmara}

Universitas Pembangunan Nasional (UPN) Veteran Jawa Timur, Indonesia

Email: qonyratnasari31@gmail.com, muljaningsihsri@gmail.com, kikyasmara25@gmail.com

\begin{tabular}{l}
\hline INFO ARTIKEL \\
\hline Diterima \\
5 Juni 2021 \\
Direvisi \\
8 Juni 2021 \\
Disetujui \\
21 Juni 2021 \\
\hline
\end{tabular}

Keywords:

inflation, interest rates, money supply, exchange rate and composite stock price index.

\begin{abstract}
This study aims to determine the effect of inflation, interest rates, money supply, and exchange rates on the composite stock price index (IHSG) listed on the Indonesia Stock Exchange in the 2010-2019 period. This study uses multiple linear regression analysis where inflation, interest rates, money supply, and currency as independent variables, and the composite stock price index (IHSG) as the dependent variable. This study uses a quantitative approach. The data used in this study are secondary data taken from periodic data on the composite stock price index listed on the Indonesia Stock Exchange from 2010 to 2019. The test results show that the inflation variable and the money supply have a positive and significant effect on the composite stock price index (IHSG). the interest rate variable has no effect on the composite stock price index (IHSG), and the exchange rate variable has a negative and significant effect on the composite stock price index (IHSG).
\end{abstract}

\begin{abstract}
ABSTRAK
Penelitian ini bertujuan untuk mengetahui pengaruh inflasi, suku bunga, jumlah uang beredar, dan kurs pada indeks harga saham gabungan (IHSG) yang terdaftar di Bursa Efek Indonesia pada periode 2010-2019. Penelitian ini menggunakan analisis regresi linier berganda dimana inflasi, suku bunga, jumlah uang beredar, dan kur sebagai variabel bebas, dan indeks harga saham gabungan (IHSG) sebagai variabel terikat. Penelitian ini menggunakan pendekatan kuantitatif dan data yang digunakan dalam penelitian ini yaitu data sekunder yang diambil dari data periodik indeks harga saham gabungan yang terdaftar di Bursa Efek Indonesia pada tahun 2010 sampai 2019. Hasil pengujian menunjukkan bahwa variabel inflasi dan jumlah uang beredar berpengaruh positif dan signifikan terhadap indeks harga saham
\end{abstract}




\begin{tabular}{ll}
\hline Kata Kunci: & gabungan (IHSG), variabel suku bunga tidak \\
inflasi, suku bunga, jumlah & berpengaruh terhadap indeks harga saham gabungan \\
uang beredar, kurs dan & (IHSG), dan variabel kurs berpengaruh negatif dan \\
indeks harga saham & $\begin{array}{l}\text { signifikan terhadap indeks harga saham gabungan } \\
\text { gabungan. }\end{array}$ \\
\hline
\end{tabular}

\section{Pendahuluan}

Dalam suatu negara faktor yang mempengaruhi perekenomian adalah investasi(Muana 2005). Akhir-akhir ini investasi diartikan sebagai kegiatan yang sering dilakukan oleh para pemangku usaha. Investasi merupakan kegiatan yang bertujuan untuk memperoleh laba dengan cara menunda konsumsi dimasa sekarang. Pasar modal merupakan sarana berlangsungnya kegiatan investasi dimana permintaan dan penawaran modal bertemu(Thobarry 2009)

Ada dua fungsi dalam pasar modal yang berpengaruh pada perekonomian negara antara lain yaitu fungsi ekonomi dan fungsi keuangan. Berikut contoh dalam fungsi ekonomi dimana pasar modal memberikan ruang untuk bertemu antara dua pihak, yaitu pihak yang mempunyai kelebihan dana (investor) dan pihak yang membutuhkan dana (emiten). Tujuan pasar modal menurut Sudarsono (2004:184) dalam (Kristianto 2012) yakni pihak yang mempunyai kelebihan dana dapat menginvestasikan dana tersebut dengan harapan mendapatkan laba (return), sedangkan perusahaan (issuer) bisa memanfaatkan dana tersebut untuk kepentingan lain tanpa menunggu tersedianya dana operasional perusahaan. Pasar modal merupakan sebuah cerminan yang biasanya disebut Indeks Harga Saham Gabungan. Ketika IHSG mengalami kenaikan hal tersebut berarti pasar modal dalam keadaan bulish, sebaliknya jika

IHSG turun maka pasar modal dalam keadaan bearish. Sehingga investor dapat memahami naik turunnya harga saham di pasar modal. Banyak faktor yang menjadi perhatian investor dalam berinvestasi antara lain contohnya yakni Indeks Harga Saham Gabungan. Hal tersebut dikarenakan indeks ini adalah composite index dari keseluruhan saham yang ada di Bursa Efek Indonesia. Dengan kata lain, dengan adanya pergerakan Indeks Harga Saham Gabungan, seorang investor harus mempunyai strategi dengan cara melihat keadaan pasar yang bisa di proksikan apakah pasar berada di fase bergairah atau lesu. Menurut (Jogiyanto 2010), Indeks Harga Saham Gabungan didefinisikan sebagai suatu trend yang diperoleh dari perhitungan indeks harga saham guna membandingkan adanya perubahan harga saham dari waktu ke waktu dengan dilakukannya pengolahan yang baik.

Faktor yang mempengaruhi investor dalam berinvestasi biasanya dengan melihat angka dalam indeks harga saham. Selain faktor internal ada faktor eksternal yang berpengaruh pada pasar modal. Banyak faktor makro ekonomi yang memiliki pengaruh dalam kegiatan investasi antara lain inflasi, tingkat suku bunga, nilai tukar rupiah terhadap dollar Amerika Serikat, JUB, indikator tersebut pada akhirnya dijadikan patokan dalam penentuan naik turunya indeks di bursa saham (Sarwono 2003). (Nugroho 2008) berpendapat bahwa tidak ada kestabilan pada nilai mata uang. Disisi lain, harga-harga barang dan jasa biasanya mengalami peningkatan. Hal tersebut 
berdampak pada menurunnya daya beli mata uang sehingga mengakibatkan terjadinya inflasi. Dengan demkian, untuk mengontrol inflasi dan nilai suku bunga. Diharapkan pemerintah membuat suatu kebijakan dalam pasar keuangan. Indikator lain yang harus diperhatikan investor dalam perekonomian yakni lebih memperhatikan adanya perubahaan jumlah uang yag beredar karena hal tersebut dapat berdampak langsung. Perubahan jumlah uang yang beredar dengan perubahan saham memiliki korelasi. Selain inflasi, suku bunga, dan jumlah uang beredar variabel lain adalah nilai tukar (kurs). Adanya keseimbangan permintaan dan penawaran terhadap mata uang dalam negeri maupun mata uang asing merupakan cerminan dari nilai tukar.

Inflasi didefinisikan sebagai kecenderungan dari harga-harga untuk menaik secara umum dan terus menerus (Apriyan 2018). Semakin meningginya angka inflasi maka akan mengakibatkan perekonomian memburuk, sehingga hal ini akan berdampak turunnya keuntungan suatu perusahaan yang mengakibatkan pergerakan harga saham (efek ekuitas) menjadi kurang kompetitif.

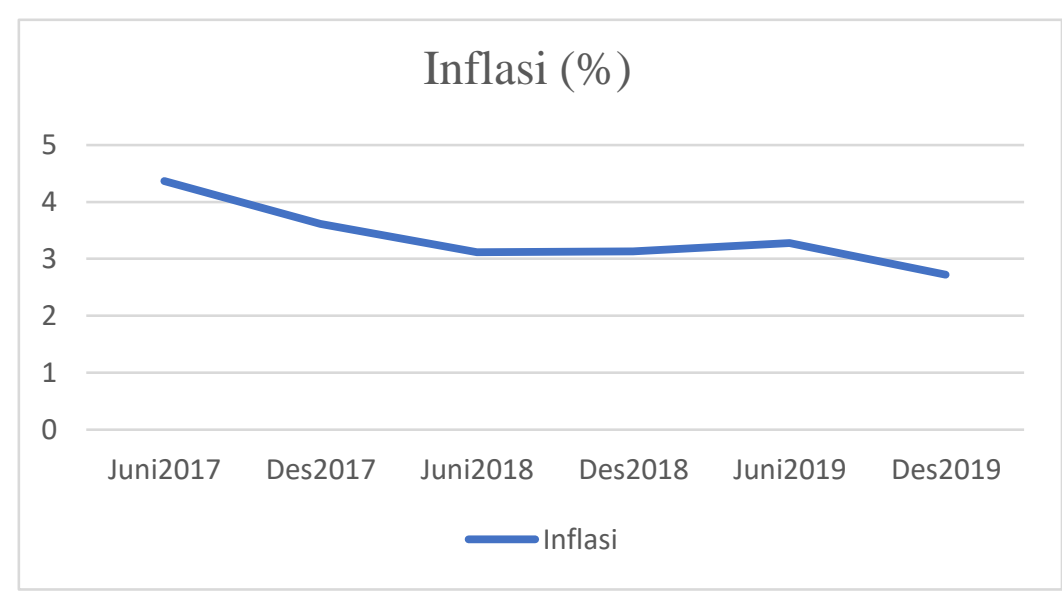

Gambar 1

Perkembangan Inflasi di Indonesia 2016-2019

Sumber: Bank Indonesia, 2021 (diolah)

Jika dilihat pada grafik inflasi diatas menunjukkan pada bulan Juni 2017 sampai Desember 2019 cenderung mengalami penurunan. Pada bulan Juni 2017 sampai Desember 2017 tingkat inflasi berada pada angka 4,37\% dan mengalami penurunan yaitu sebesar 3,61\%. Kemudian di bulan Juni 2018 sampai Desember 2018 angka inflasi naik sedikit sebesar 3,12\% menjadi 3,13\%. Pada bulan Juni 2019 sampai Desember 2019 angka tersebut mengalami penurunan kembali sebesar 3,28\% menjadi 2,72\%.

Salah satu variabel yang dapat mempengaruhi harga saham adalah tingkat suku bunga. Diasumsikan suku bunga SBI naik, maka investor akan lebih tertarik untuk menginvestasikan dananya dalam deposito atau tabungan dibank dengan pendapatan yang lebih tinggi dibandingkan dengan pasar modal yang berisiko lebih tinggi (Amin,2012). 


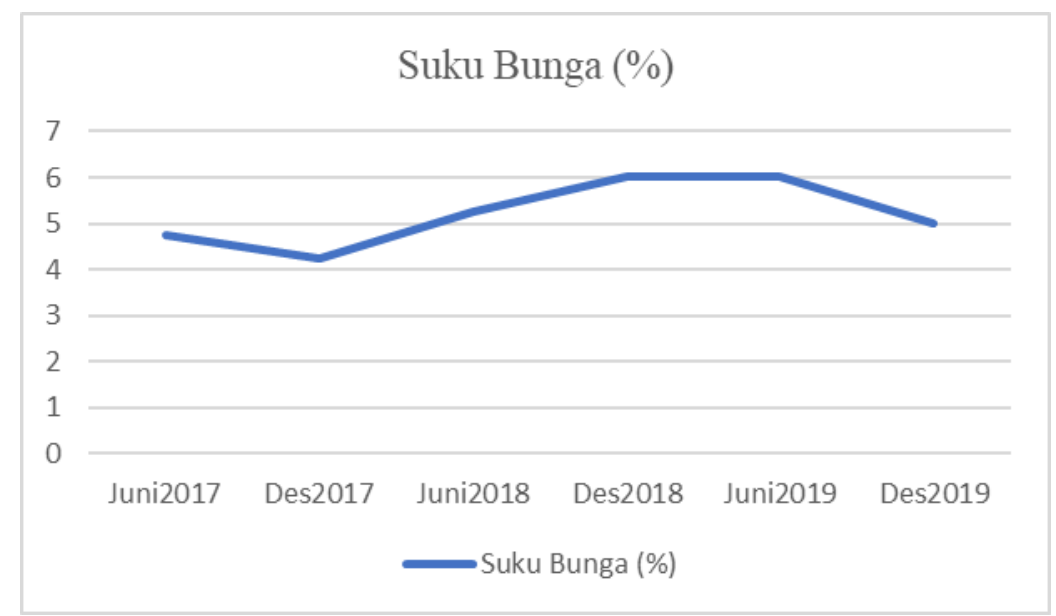

\section{Gambar 2}

Perkembangan Tingkat Suku Bunga di Indonesia 2016-2019

Sumber : Bank Indonesia, 2021 (diolah)

Jika dilihat pada perkembangan tingkat suku bunga pada bulan Juni 2017-bulan Desember 2019 cenderung fluktuatif naik turun. Pada Juni 2017 tingkat suku bunga berada pada angka 4,75\% dan turun menjadi 4,25\% pada Desember 2017. Berbeda dengan bulan Juni 2018 tingkat suku bunga naik 5,25\% menjadi 6,00\% pada Desember 2018. Sedangkan bulan Juni 2019 suku bunga turun kembali sebesar 6,00\% menjadi 5,00\% pada Desember 2019.

Keseluruhan jumlah mata uang yang telah diedarkan oleh bank sentral disebut jumlah uang beredar Pendistrbusian mata uang tersebut terdiri dari dua jenis yakni uang kertas dan uang logam. Permintaan terhadap uang naik seiring dengan naiknya pendapatan dan turun seiring dengan naiknya pendapatan dan turun seiring dengan meningkatnya suku bunga (Dornbusch and Fischer 1980).

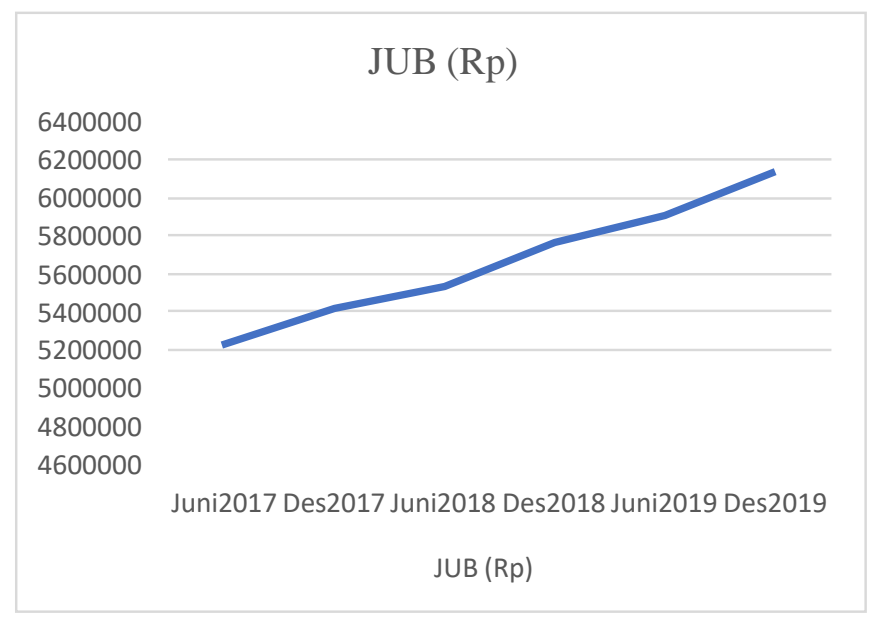

Gambar 3

Perkembangan Jumlah Uang Beredar di Indonesia 2016-2019

Sumber : Badan Pusat Statistik, 2021 (diolah) 
Dapat dilihat pada grafik diatas bahwa pada bulan Juli 2017 sampai Desember 2019 jumlah uang beredar mengalami kenaikan secara signifikan dari angka Rp.5.225.165,76 Juni 2017 menjadi Rp.5.419.165,05 Desember 2017. Pada Juni 2018 sebesar Rp.5.534.149,83 menjadi Rp.5.760.046,20 Desember 2018, dan terakhir dibulan Juni 2019 sebesar Rp.5.908.509,27 menjadi Rp.6.136551,81 Desember 2019.

Variabel terakhir adalah kurs (nilai tukar). Menurut (Thobarry 2009) definisi nilai tukar merupakan perbandingan harga mata uang suatu negara terhadap negara lainnya. Menurut (Kaluge, Tufail, and Muneer 2017) sinyal positif bagi investor yaitu ketika terjadinya penguatan kurs rupiah terhadap mata uang asing. Kurs rupiah terhadap mata uang asing yang mengalami penguatan akan mengakibatkan banyak investor berinvestasi pada saham.

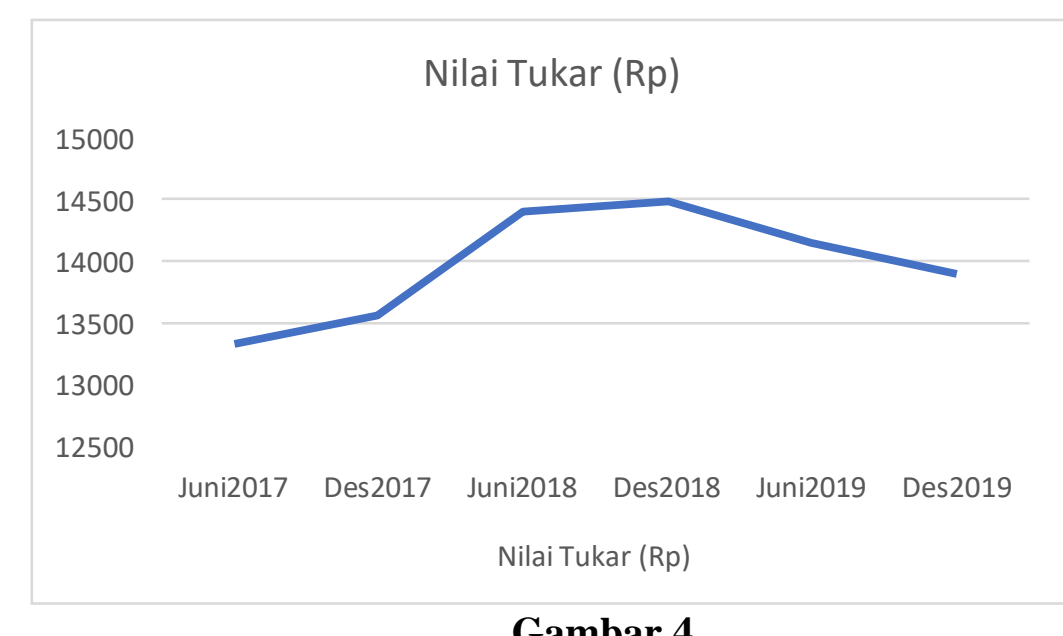

\section{Perkembangan Nilai Tukar (kurs) 2016-2019}

Sumber: Bank Indonesia, 2021 (diolah)

Jika dilihat kurs dari bulan Juni 2017 sampai Desember 2018 cenderung mengalami fluktuatif naik dimana pada Juni 2017 sebesar Rp. 13.319, Desember 2017 sebesar Rp. 13.548, dan Juni 2018 sebesar Rp. 14.404, Desember 2018 sebesar Rp.14.481. Namun pada Juni 2019, nilai tukar mengalami sedikit penurunan sebesar Rp. 14.141 menjadi 13.901 pada Desember 2019.

Fenomena yang terjadi yakni kenaikan IHSG tak selamanya diiringi oleh kenaikan faktor makro ekonomi misalnya inflasi, tingkat suku bunga dan nilai tukar rupiah. Hal ini terlihat dari data di Bursa Efek Indonesia bahwa pada tahun 2019 IHSG mengalami kenaikan dari angka 6194,50 menjadi 6299,54. Hal ini berbanding terbalik dimana pada tahun 2019 tingkat inflasi mengalami penurunan dari angka 3,12\% menjadi 2,72\% dan tingkat suku bunga juga mengalami penurunan dari 6,00\% menjadi 5,00\%. Sedangkan nilai tukar mengalami penurunan dari angka Rp.14.481 menjadi Rp. 13.901. Berbeda dengan variabel Jumlah uang beredar yang mengalami kenaikan pada tahun 2019 dari angka Rp. 5.760.046,20 menjadi Rp. 6.136.551,81. Dari permasalahan tersebut dapat dilihat bahwa terjadi kejanggalan yang seharusnya IHSG memiliki pengaruh yang searah namun pada kenyataannya IHSG memiliki pengaruh yang berlawanan arah. 
Diantara berbagai kegiatan internasional, perdagangan dan aliran dana adalah penyebab utama volatilitas di sektor ekonomi, khususnya pasar saham.

Berdasarkan pemaparan diatas maka peneliti merasa tertarik untuk meneliti kembali karena tidak konsistennya berbagai hasil penelitian sebelumnya mengenai indeks harga saham gabungan tersebut menjadi motivator utama penulis untuk melakukan penelitian ini. Perbedaan penelitian ini dengan peneliti terdahulu adalah penelitian ini lebih menfokuskan pada Indeks Harga Saham Gabungan yang di pengaruhi Inflasi, Suku Bunga, Jumlah Uang beredar dan Kurs pada periode 2010-2019. Penulis hanya mengambil rentang waktu selama 10 tahun yaitu tahun 2010-2019 karena dengan membatasi rentang waktu penelitian maka penelitian akan lebih mempresentasikan IHSG dalam kondisi perekonomian yang terjadi pada saat tersebut. Selain itu, kondisi perekonomian di Indonesia cenderung berubah-ubah dan tidak stabil sehingga akan mempengaruhi penelitian. Kondisi perekonomian di Indonesia pada tahun penelitian dapat dikatakan sedang lemah. Berdasarkan latar belakang yang telah diuraikan di atas, maka diperoleh rumusan masalah dalam penelitian ini adalah sebagai berikut: (1) Apakah terdapat pengaruh Inflasi terhadap Indeks Harga Saham Gabungan (IHSG) di Bursa Efek Indonesia (BEI), (2) Apakah terdapat pengaruh Suku Bunga terhadap Indeks Harga Saham Gabungan (IHSG) di Bursa Efek Indonesia (BEI) (3) Apakah terdapat pengaruh Jumlah Uang Beredar (JUB) terhadap Indeks Harga Saham Gabungan (IHSG) di Bursa Efek Indonesia (BEI) (4) Apakah terdapat pengaruh Nilai Tukar/Kurs terhadap Indeks Harga Saham Gabungan (IHSG) di Bursa Efek Indonesia (BEI)

\section{Metode Penelitian}

Pendekatan penelitian ini mengidentifikasikan tentang keseluruhan aspek penelitian yang digunakan. Dalam penelitian ini menggunakan pendekatan kuantitatif. Pendekatan kuantitatif ini menjelaskan apakah ada hubungan antar variabel dalam penelitian dan menguji hipotesis atau teori yang akan diteliti.

Dalam penelitian ini jenis data yang digunakan dalam penelitian yaitu data sekunder yaitu jenis data yang diperoleh secara tidak langsung dari sumber pertama melainkan dari beberapa lembaga atau instansi yang memiliki kaitan dalam penelitian atau data yang telah dipublikasikan dari kumpulan data Lembaga atau instansi yang berkaitan.

Metode pengumpulan data yang dipakai yaitu dengan memakai metode dokumentasi, dimana metode tersebut digambarkan dengan mencatat dan mengcopy data-data tertulis yang berhubungan dengan masalah penelitian antara lain bersumber dari dokumen/buku-buku, koran, majalah, internet dan lain lain mengenai tingkat inflasi, tingkat suku bunga, jumlah uang beredar, nilai tukar (kurs) dan Indeks Harga Saham Gabungan (IHSG) berupa data per semester pada periode 2010- 2019.

Teknik analisis data yang digunakan dalam penelitian ini adalah dengan menggunakan analisis regresi linier berganda untuk memperoleh gambaran yang menyeluruh mengenai hubungan antara variabel independen yakni tingkat inflasi, 
tingkat suku bunga, jumlah uang beredar, dan nilai tukar(kurs) terhadap variabel dependen yakni indeks harga saham gabungan di BEI.

\section{Hasil dan Pembahasan}

A. Analisis Regresi Linear Berganda

Persamaan regresi ini dilakukan untuk menguji pengaruh inflasi, suku bunga, jumlah uang beredar dan kurs terhadap IHSG. Berdasarkan hasil analisis diperoleh persamaan regresi linear berganda yang tersaji dalam Tabel 1.

\section{Tabel 1}

Analisis Regresi Linier Berganda Coefficientsa

\begin{tabular}{|c|c|c|c|c|c|c|}
\hline \multirow[t]{2}{*}{ Model } & \multicolumn{2}{|c|}{ Unstandardized Coefficients } & \multicolumn{4}{|c|}{ Standardized Coefficients } \\
\hline & & B & Std. Error & Beta & $\mathbf{t}$ & Sig. \\
\hline 1 & (Constant) & 2467,433 & 434,662 & & 5,677 & 0,000 \\
\hline & $\mathrm{X} 1$ & 139.727 & 38,960 & 0,255 & 3,586 & 0,003 \\
\hline & $\mathrm{X} 2$ & $-46,668$ & 80,449 & $-0,048$ & $-0,580$ & 0,570 \\
\hline & $\mathrm{X} 3$ & 0,001 & 0,000 & 1,696 & 7,487 & 0,000 \\
\hline & $\mathrm{X} 4$ & $-0,313$ & 0,97 & $-0,666$ & $-3,216$ & 0.006 \\
\hline
\end{tabular}

a. Dependent Variable: $\mathrm{Y}$

Sumber: Data sekunder diolah (2021)

Berdasarkan Tabel 1 diatas, diperoleh persamaan regresi sebagai berikut: $\mathrm{Y}=$ $2467,433+139,727 \mathrm{X} 1+(-46,668 \mathrm{X} 2)+0,001 \mathrm{X} 3+(-0,313 \mathrm{X} 4)+\mathrm{e}$

1. Uji Kelayakan

a. Model Uji F

Pengujian ini bertujuan untuk menguji apakah model (sesuai) fit atau tidak (Ghozali, 2018). Uji F dilakukan dengan melihat signifikansi F pada output hasil regresi dengan signifikansi $0,05(\mathrm{a}=5 \%)$. Berdasarkan Tabel 2 menunjukkan bahwa nilai $\mathrm{F}$ hitung sebesar 105,75 dengan nilai signifikansi 0,000 sehingga model ini layak untuk digunakan.

\section{Tabel 2}

Uji Statistik F

ANOVAa

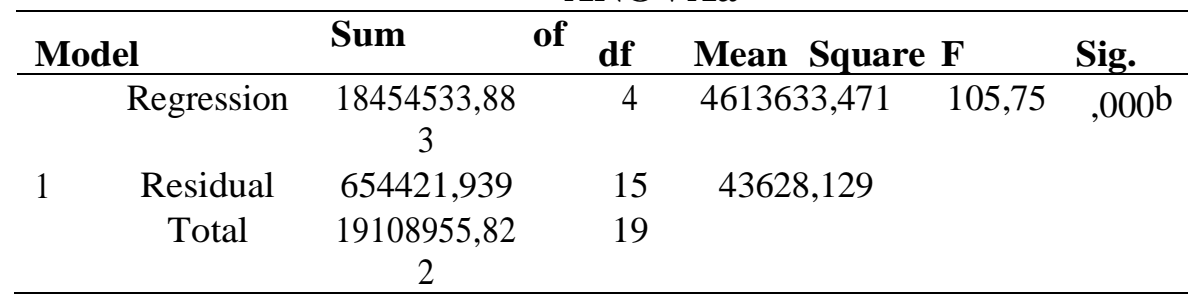

a. Dependent Variable: $\mathrm{Y}$

b. Predictors: (Constant), X4, X2, X1, X3 
b. Uji Koefisien Determinasi (R2)

Koefisien determinasi (R2) pada intinya seberapa jauh dalam mengukur kemampuan model yang menerangkan variabel dependen. Hasil koefisien determinasi pada Tabel 3 .

Tabel 3

Uji Koefisien Determinasi R2 Model Summaryb

\begin{tabular}{ccccc}
\hline Model & R & R Square & $\begin{array}{c}\text { Adjusted } \\
\text { R Square }\end{array}$ & $\begin{array}{c}\text { Std. Error of the } \\
\text { Estimate }\end{array}$ \\
\hline $\mathbf{1}$ & $0,983 \mathrm{a}$ & 0,966 & 0,957 & 208,87348 \\
\hline
\end{tabular}

a. Predictors: (Constant), X4, X2, X1, X3

b. Dependent Variable: Y

Sumber: Data sekunder diolah (2021)

Berdasarkan Tabel 3 menunjukkan bahwa nilai koefisien determinasi sebesar yang terdapat dikolom R square sebesar 0,966 atau 96,6\% untuk inflasi, suku bunga, jumlah uang beredar, kurs dan sisanya dijelaskan oleh variabel lain diluar model.

c. Uji Hipotesis (Uji t)

Pengujian dilakukan dengan menggunakan significance level 0,05 (a = $5 \%$ ). Apabila nilai signifikansi $<5 \%$ maka dinyatakan layak, dan apabila nilai signifikansi $>5 \%$ maka dinyatakan tidak layak. Hasil pengujian dari hipotesis terhadap nilai signifikansi dapat disajikan dalam Tabel 4.

Tabel 4

Uji T Coefficientsa

\begin{tabular}{cccllll}
\hline Model & Unstandardized Coefficients & \multicolumn{4}{c}{ Standardized Coefficients } \\
\hline & & B & Std. Error & Beta & t & Sig. \\
\hline $\mathbf{1}$ & (Constant) & 2467,433 & 434,662 & & 5,677 & 0,000 \\
\hline & X1 & 139.727 & 38,960 & 0,255 & 3,586 & 0,003 \\
\hline & X2 & $-46,668$ & 80,449 & $-0,048$ & $-0,580$ & 0,570 \\
\hline & X3 & 0,001 & 0,000 & 1,696 & 7,487 & 0,000 \\
\hline & X4 & $-0,313$ & 0,97 & $-0,666$ & $-3,216$ & 0.006 \\
\hline
\end{tabular}

a. Dependent Variable: Y

Sumber: Data sekunder diolah (2021)

Berdasarkan Tabel 4 diatas diperoleh hasil perhitungan $\mathrm{t}$ berserta tingkat signifikansi dengan penjelasan sebagai berikut: 1 . Uji pengaruh inflasi terhadap IHSG memiliki t hitung sebesar 3,586 dengan nilai signifikansi 0,003, maka dapat disimpulkan bahwa inflasi berpengaruh positif dan signifikan terhadap inflasi. 2. Uji pengaruh suku bunga terhadap IHSG memiliki t hitung sebesar 0,580 dengan nilai signifikansi 0,580 , maka dapat disimpulkan bahwa suku bunga tidak berpengaruh terhadap IHSG. 3. Uji pengaruh jumlah uang beredar memiliki t hitung sebesar 7,487 dengan nilai signifikansi 0,000, maka dapat dikatakan bahwa jumlah uang beredar berpengaruh positif dan signifikan terhadap IHSG. 4. Uji pengaruh kurs terhadap IHSG memiliki t hitung sebesar 
-3,216 dengan nilai signifikansi 0,000, maka dapat dikatakan bahwa kurs berpengaruh negative dan signifikan terhadap IHSG.

2. Uji Asumsi Uji Normalitas

a. Pendekatan Grafik

Dalam penelitian ini gambar grafik normal plot pada Gambar 6 menunjukkan bahwa pola data menyebar disekitar diagonal dan mengikuti arah garis diagonal, sehingga dapat dikatakan bahwa variabel dalam penelitian ini sudah memenuhi uji normalitas.

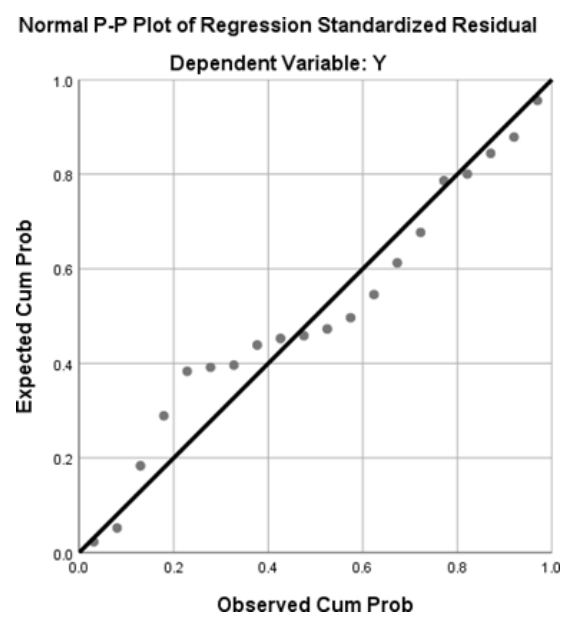

\section{Gambar 6}

\section{Uji Normalitas (Grafik Normal P-P Plot)}

Sumber: Data sekunder diolah (2021)

b. Pendekatan Kolmogorov-Smirnov

Dalam penelitian ini mengetahui normal tidaknya dengan menggunakan uji One- Sample Kolmogorov-Smirnov Test berdasarkan taraf signifikansi pada hasil hitungan. Hasil uji One-Sample Kolmogorov-Smirnov Test disajikan pada Tabel 5

\section{Tabel 5}

Uji Pendekatan Kolmogorov-Smirnov

\begin{tabular}{|c|c|c|}
\hline \multicolumn{3}{|c|}{ One-Sample Kolmogorov-Smirnov Test } \\
\hline & & $\begin{array}{l}\text { Unstandardized } \\
\text { Residual }\end{array}$ \\
\hline $\mathrm{N}$ & & 20 \\
\hline \multirow[b]{2}{*}{$\begin{array}{l}\text { Normal } \\
\text { Parameter } \\
\text { sa,b }\end{array}$} & Mean & .0000000 \\
\hline & $\begin{array}{l}\text { Std. } \\
\text { Deviatio } \\
n\end{array}$ & 18.558.895.428 \\
\hline \multirow{3}{*}{$\begin{array}{ll}\text { Most } & \\
\text { me } & \text { Extre }\end{array}$} & Absolute & .169 \\
\hline & Positive & .104 \\
\hline & Negative & -.169 \\
\hline
\end{tabular}




\begin{tabular}{ll}
\hline Test Statistic & $\mathbf{. 1 6 9}$ \\
\hline Asymp. Sig. (2-tailed) & $\mathbf{. 1 3 6} \mathbf{c}$ \\
\hline a. Test distribution is \\
Normal. \\
\hline b. Calculated from data. \\
\hline Sumber: Data sekunder diolah (2021)
\end{tabular}

Berdasarkan Tabel 5 dapat diketahui bahwa besarnya nilai asymp. sig. (2-tailed) sebesar $0.136>0.05$, hal ini sesuai dengan ketentuan yang telah ditetapkan, maka dapat disimpulkan bahwa data berdistribusi normal untuk variabel profitabilitas.

3. Uji Multikolinearitas

Model regresi yang baik seharusnya tidak terjadi korelasi diantara variabel independen. Untuk mendeteksi ada dan tidaknya multikolinieritas didalam model regresi ini yaitu dengan cara melihat nilai tolerance $>0.10$ dan nilai Variance inflation Factor (VIF) $<10$.

Tabel 6

Uji Multikolinearitas

\begin{tabular}{|c|c|c|c|c|}
\hline \multirow{2}{*}{ Model } & & \multicolumn{2}{|c|}{ Collinearity Statistics } & \multirow{2}{*}{ Keterangan } \\
\hline & & Tolerance & VIF & \\
\hline \multirow[t]{5}{*}{1} & (Constant) & & & \\
\hline & $\mathrm{X} 1$ & 0,450 & 2,223 & $\begin{array}{l}\text { Tidak terjadi } \\
\text { multikolinieritas }\end{array}$ \\
\hline & $\mathrm{X} 2$ & 0,327 & 3,061 & $\begin{array}{l}\text { Tidak terjadi } \\
\text { multikolinieritas }\end{array}$ \\
\hline & $\mathrm{X} 3$ & 0,144 & 6,474 & $\begin{array}{l}\text { Tidak terjadi } \\
\text { multikolinieritas }\end{array}$ \\
\hline & $\mathbf{X} 4$ & 0,153 & 3,786 & $\begin{array}{l}\text { Tidak terjadi } \\
\text { multikolinieritas }\end{array}$ \\
\hline
\end{tabular}

a. Dependent Variable: Y

Sumber: Data sekunder diolah (2021)

Dari Tabel 6 diatas menunjukkan bahwa inflasi, suku bunga, jumlah uang beredar dan kurs memiliki nilai Tolerance $>0,10$ dan VIF $<10$ maka Tabel diatas dinyatakan bebas dari multikolinearitas untuk variabel IHSG.

4. Uji Heteroskedastisitas

Uji heteroskedastisitas bertujuan menguji apakah dalam model regresi terjadi ketidaksamaan variance dari residual satu pengamatan ke pengamatan yang lain. 


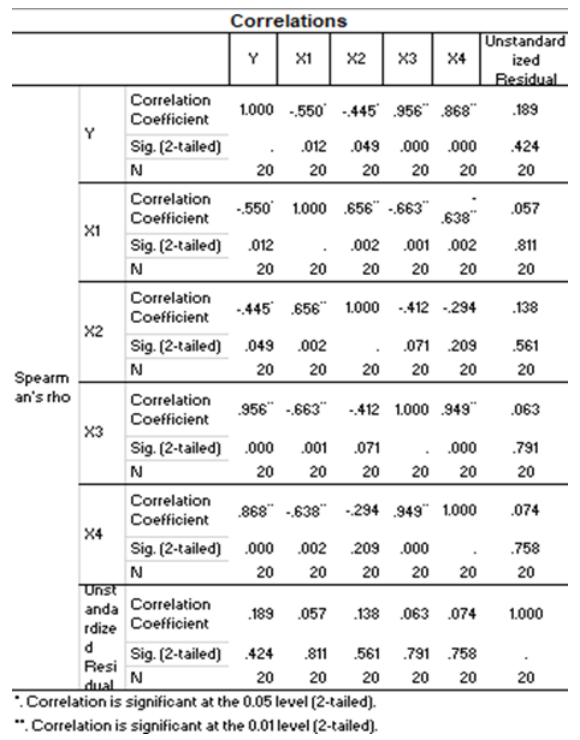

\section{Gambar 7}

Uji Heteroskedastisitas

Sumber: Data sekunder diolah, (2021)

Berdasarkan Gambar 7 diatas menunjukkan bahwa inflasi, suku bunga, jumlah uang beredar dan kurs memiliki nilai signifikansi $>0,05$. Hal ini dapat dikatakan bahwa model ini layak untuk digunakan karena tidak terjadi heteroskedastisitas.

5. Uji Autokolerasi

Cara untuk mendeteksi adanya autokolerasi adalah dengan melihat Durbin Watson dengan ketentuan -2 sampai 2 tidak terjadi autokulorasi maka dapat disimpulkan bahwa tidak terjadi autokolerasi pada Tabel 7 karena menunjukkan nilai Durbin Watson sebesar 2,124.

Tabel 7

Uji Autokorelasi Model Summaryb

\begin{tabular}{ll|l|l|l|l}
\hline Model & $\mathbf{R}$ & $\begin{array}{l}\mathbf{R} \\
\text { Square }\end{array}$ & $\begin{array}{l}\text { Adjusted } \mathbf{R} \\
\text { Square }\end{array}$ & $\begin{array}{l}\text { Std. Error of } \\
\text { the Estimate }\end{array}$ & $\begin{array}{l}\text { Durbin- } \\
\text { Watson }\end{array}$ \\
\hline 1 & ,983a & 0,966 & 0,957 & 208,873448 & 2,124 \\
\hline
\end{tabular}

a. Predictors: (Constant), X4, X2, X1, X3

b. Dependent Variable: Y

Sumber: Data sekunder diolah (2021)

\section{B. Pembahasan}

1. Pengaruh Inflasi terhadap Indeks Harga Saham Gabungan

Berdasarkan hasil pengujian pada tabel 4 pengaruh inflasi terhadap IHSG menghasilkan nilai koefisien (standardized coefficient) positif sebesar 0,255 dengan signifikansi value sebesar 0,003. Oleh karena itu, sig value $0,003<$ sig tolerance 0,05 , maka hipotesis satu diterima, karena pengaruh inflasi 
terhadap IHSG terbukti signifikan. Artinya adanya hubungan searah yakni ketika inflasi naik maka indeks harga saham gabungan juga ikut naik. Hal ini sesuai dengan pendapat (Reilly dalam Wijayanti, 2013) yang didasarkan pada asumsi bahwa inflasi yang terjadi adalah Demand Pull Inflation, yaitu inflasi yang terjadi disebabkan adanya permintaan yang tinggi atas penawaran barang yang tersedia. Pada keadaan ini, perusahaan dapat membebankan peningkatan biaya kepada konsumen dengan proporsi yang lebih besar sehingga keuntungan perusahaan meningkat dan juga akan meningkatkan kempampuan perusahaan untuk membayarkan deviden serta memberikan penilaian positif pada harga saham, sehingga minat investor untuk berinvestasi pada saham menjadi meningkat dan indeks harga saham gabungan juga ikut meningkat.

2. Pengaruh Suku Bunga terhadap Indeks Harga Saham Gabungan

Berdasarkan hasil pengujian pada tabel 4 pengaruh suku bunga terhadap IHSG menghasilkan nilai koefisien (standardized coefficient) negative sebesar 0,048 dengan signifikansi value sebesar 0,570. Oleh karena itu, sig value 0,570 > sig tolerance 0,05 , maka hipotesis dua ditolak, karena pengaruh suku bunga terhadap IHSG terbukti tidak signifikan. Hasil penelitian Wijaya (2013) yang menyatakan bahwa suku bunga tidak berpengaruh signifikan terhadaap IHSG. Hal ini menunjukkan bahwa suku bunga masih bukan parameter instrument investasi yang menjadi acuan bagi masyarakat, data menunjukkan bahwa nilai tertinggi suku bunga sebesar 7,75 persen terjadi pada tahun 2014, pada tahuntahun berikut suku bunga mengalami penurunan yang cukup signifikan dengan nilai terendah 4,25 persen terjadi pada tahun 2017, oleh karena itu suku bunga yang rendah masyarakat mengalihkan investasinya ke sektor lain diantaranya adalah investasi pada pasar saham, sehingga mengakibatkan kinerja pasar saham menjadi baik. Hasil penelitian ini menunjukkan bahwa besar kecilnya tingkat suku bunga tidak mempengaruhi IHSG, Suku bunga bisa mempengaruhi suku bunga deposito dan tabungan yang merupakan salah satu alternatif bagi investor untuk menginvestasikan modalnya. Dengan demikian tingkat suku bunga bisa mempengaruhi nilai investor dalam menanamkan modalnya dalam bentuk saham.

3. Pengaruh Jumlah Uang Beredar terhadap Indeks Harga Saham Gabungan

Berdasarkan hasil pengujian pada tabel 4 pengaruh jumlah uang beredar terhadap IHSG menghasilkan nilai koefisien (standardized coefficient) positif sebesar 1,696 dengan signifikansi value sebesar 0,000. Oleh karena itu, sig value $0,000<$ sig tolerance 0,05 , maka hipotesis tiga diterima, karena pengaruh jumlah uang beredar terhadap IHSG terbukti signifikan dengan arah yang positif. artinya adanya hubungan searah yakni ketika jumlah uang beredar naik maka indeks harga saham gabungan juga ikut naik. Hasil penelitian ini sesuai dengan penelitian (Wibowo, Arifati, and Raharjo 2016) yang menyatakan bahwa ketika jumlah uang beredar, yang terdiri dari Uang Kartal, Uang Giral Uang Kuasi dan Surat Berharga mengalami kenaikan yang menandakan adanya kenaikan 
produktivitas perekonomian Indonesia akan berdampak pada banyaknya lapangan pekerjaan sehingga meningkatkan pendapatan pada masayarakat. Kenaikan Uang Kartal (logam dan kertas) memperlihatkan adanya peningkatan daya beli masyarakat yang disebabkan dengan meningkatnya pendapatan masyarakat itu sendiri. Sedangkan disisi Uang Giral (deposito, tabungan, giro), Uang Kuasi (deposito berjangka) dan Surat Berharga, kenaikan jumlah uang beredar memperlihatkan adanya peningkatan kemampuan masyarakat dalam menyisihkan pendapatan mereka untuk ditabung dan diinvestasikan, setelah dikurangi dengan konsumsi mereka. Temuan ini tidak sejalan dengan penelitian dari (Wijaya 2013) yang menyatakan bahwa jumlah uang beredar tidak berpengaruh signifikan terhadap IHSG.

4. Pengaruh Kurs terhadap Indeks Harga Saham Gabungan

Berdasarkan hasil pengujian pada tabel 4 pengaruh kurs terhadap IHSG menghasilkan nilai koefisien (standardized coefficient) negatif sebesar 0,666 dengan signifikansi value sebesar 0,000. Oleh karena itu, sig value $0,000<$ sig tolerance 0,05 , maka hipotesis empat diterima, karena pengaruh jumlah uang beredar terhadap IHSG terbukti signifikan. Artinya adanya hubungan berlawanan arah yakni ketika kurs turun (menguat) maka indeks harga saham Gabungan akan mengalami kenaikan. Hasil penelitian ini konsisten dengan penelitian(Kewal 2012), Jika kurs rupiah turun (menguat) maka kondisi perkonomian di Indonesia akan meningkat serta pasar modal juga ikut meningkat sehingga mengakibatkan IHSG mengalami peningkatan.

Menguatnya kurs rupiah akan menurunkan biaya produksi diikuti dengan menurunnya tingkat bunga, hal ini akan memberikan dampak positif pada laba perusahaan yang akhirnya akan menaikkan tingkat pendapatan per lembar ssham. Begitu juga sebaliknya jika kurs rupiah naik (melemah) maka IHSG akan mengalami penurunan. Hal ini didukung oleh pendekatan tradisional, yang menyatakan adanya hubungan antara kurs rupiah dengan harga saham adalah adalah negatif dimana nilai tukar mempengaruhi kompetitifnya suatu perusahaan.

\section{Kesimpulan}

Berdasarkan hasil dan pembahasan diperoleh simpulan bahwa hasil dari penelitian menunjukkan bahwa inflasi berpengaruh positif dan signifikan terhadap indeks harga saham gabungan maka dapat disimpulkan bahwa H1 diterima, hasil dari penelitian menunjukkan bahwa suku bunga berpengaruh negatif dan tidak signifikan terhadap indeks harga saham gabungan maka dapat disimpulkan bahwa $\mathrm{H} 2$ ditolak, hasil dari penelitian menunjukkan bahwa jumlah uang beredar berpengaruh positif dan signifikan terhadap indeks harga saham gabungan, maka dapat disimpulkan bahwa H3 diterima, hasil dari penelitian menunjukkan bahwa kurs berpengaruh negatif dan signifikan terhadap indeks harga saham gabungan maka dapat disimpulkan bahwa $\mathrm{H} 4$ diterima. 
Pengaruh Faktor Makro Ekonomi terhadap Indeks Harga Saham Gabungan di Bursa Efek Indonesia (Periode 2010-2019)

\section{BIBLIOGRAFI}

Apriyan, Rizal. 2018. “Analisis Pengaruh Nilai Tukar (Kurs), Inflasi Dan Suku Bunga (BI Rate) Terhadap Indeks Harga Saham Gabungan (IHSG)(Studi Pada Perusahaan Property Dan Real Estate Yang Terdaftar Di Bursa Efek Indonesia (BEI Periode2011-2015).Google Scholar

Dornbusch, Rudiger, and Stanley Fischer. 1980. "Exchange Rates and the Current Account." The American Economic Review 70(5): 960-71.Google Scholar

Jogiyanto, Hartono. 2010. "Teori Portofolio Dan Analisis Investasi." Edisi Ketujuh. BPFE. Yogyakarta.Google Scholar

Kaluge, David, Muhammad Shahid Tufail, and Saqib Muneer. 2017. "Multifactor on Macroeconomic Fundamentals to Explain the Behavior of Sectoral Indices in Indonesian Stock Exchange." City University Research Journal, Special Issue: AIC, Malaysia: 276-82.Google Scholar

Kewal, Suramaya Suci. 2012. "Pengaruh Inflasi, Suku Bunga, Kurs, Dan Pertumbuhan PDB Terhadap Indeks Harga Saham Gabungan.” Jurnal economia 8(1): 53-64 Google Scholar.

Kristianto, Djoko. 2012. "Implikasi Akuntansi Syariah Dan Asuransi Syariah Dalam Lembaga Keuangan Syariah.” Jurnal Akuntansi dan Sistem Teknologi Informasi 7(1).Google Scholar

Muana, Nanga. 2005. "Makroekonomi: Teori, Masalah, Dan Kebijakan, Edisi Kedua." Jakarta: Rajawali Pers.Google Scholar

Nugroho, Heru. 2008. “Analisis Pengaruh Inflasi, Suku Bunga, Kurs Dan Jumlah Uang Beredar Terhadap Indeks LQ45 (Studi Kasus Pada BEI Periode 20022007).”Google Scholar

Sarwono, Djoko. 2003. "Analisa Beberapa Faktor Yang Memperngaruhi Perubahan Harga Saham Perusahaan Go Publik Di BES." Universitas Brawijaya, Tidak Dipublikasikan.Google Scholar

Thobarry, Achmad Ath. 2009. “Analisis Pengaruh Nilai Tukar, Suku Bunga, Laju Inflasi Dan Pertumbuhan GDP Terhadap Indeks Harga Saham Sektor Properti (Kajian Empiris Pada Bursa Efek Indonesia Periode Pengamatan Tahun 20002008).”Google Scholar

Wibowo, Feri, Rina Arifati, and Kharis Raharjo. 2016. "Analisis Pengaruh Tingkat Inflasi, Suku Bunga Sbi, Nilai Tukar Us Dollar Pada Rupiah, Jumlah Uang Beredar, Indeks Dow Jones, Indeks Nikkei 225, Dan Indeks Hangseng Terhadap Pergerakan Indeks Harga Saham Gabungan (Ihsg) Periode Tahun 2010-2014." Journal Of Accounting 2(2).Google Scholar 
Qony Ratnasari, Sri Muljaningsih, Kiki Asmara

Wijaya, Bambang Sukma. 2013. "Dimensions of Brand Image: A Conceptual Review from the Perspective of Brand Communication." European Journal of Business and Managemrnt 5(31): 55-65Google Scholar.

\section{Copyright holder :}

Qony Ratnasari, Sri Muljaningsih, dan Kiki Asmara (2021)

\section{First publication right:}

Jurnal Syntax Admiration

This article is licensed under:

(c) $\oplus \ominus_{\mathrm{NY}}$ 